\title{
Prevalence of bronchial reactivity to inhaled methacholine in New Zealand children
}

\author{
MALCOLM R SEARS, DAVID T JONES, M DAVID HOLDAWAY, \\ CHRIS J HEWITT, ERIN M FLANNERY, G PETER HERBISON, PHIL A SILVA \\ From the Departments of Medicine, Paediatrics and Child Health, and Preventive and Social Medicine and \\ the Dunedin Multidisciplinary Health and Development Research Unit, University of Otago Medical School, \\ Dunedin, New Zealand
}

\begin{abstract}
The prevalence of bronchial hyperreactivity to inhaled methacholine and of a clinical history of symptoms of asthma was determined in a birth cohort of 9 year old New Zealand children. A history of current or previous recurrent wheezing was obtained in 220 of 815 children. Of 800 who had spirometric tests, $27(3.4 \%)$ had resting airflow obstruction $\left(\mathrm{FEV}_{1} / \mathrm{FVC}<75 \%\right)$. Methacholine challenge was undertaken without problem in 766 children, the abbreviated protocol being based on five breaths and four concentrations. A fall in $\mathrm{FEV}_{1}$ of more than $20 \%$ was observed in 176 children $(23 \%$ of challenges, $22 \%$ of the full cohort) after inhalation of methacholine in concentrations of up to $25 \mathrm{mg} / \mathrm{ml}$. The prevalence of bronchial reactivity in children with symptoms was related to the frequency of wheezing episodes in the last year, and the degree of reactivity to the interval since the last episode. Sixty four children $(8.0 \%)$ with no history of wheeze or recurrent dry cough were, however, also responsive to methacholine $25 \mathrm{mg} / \mathrm{ml}$ or less, while $35 \%$ of children with current or previous wheezing did not respond to any dose of methacholine. Bronchial challenge by methacholine inhalation was not sufficiently sensitive or specific to be useful as a major criterion for the diagnosis of asthma in epidemiological studies. The occurrence of airway reactivity in children without symptoms of asthma, however, raises the possibility that adult onset asthma and the development of airways obstruction in some subjects with chronic bronchitis could have origins in childhood.
\end{abstract}

Asthma, although one of the most common diseases of childhood, is underdiagnosed and undertreated. ${ }^{1-3}$ The prevalence of childhood asthma is difficult to determine with certainty; estimates in New Zealand have ranged from $5 \%$ to $25 \% .^{14-7}$ We have previously reported a high prevalence of a history of wheezing in 7 year old children. ${ }^{1}$ Our results were in keeping with Australian findings that $11-12 \%$ of children have clinically important wheezing in the first 7-10 years of life, and that a further $20 \%$ may have mild or trivial wheezing not labelled as asthma. ${ }^{89}$ Some of the variation in reported prevalence is attributable to differing interpretations of a history of wheezing, and the demonstration of bronchial reac-

\footnotetext{
Address for reprint requests: Dr MR Sears, Department of Medicine, University of Otago Medical School, PO Box 913, Dunedin, New Zealand.
}

Accepted 14 October 1985 tivity has been suggested as the ultimate standard for the diagnosis of asthma. ${ }^{1011}$ Non-specific bronchial reactivity to methacholine and histamine and to exercise has been well documented in subjects with symptomatic asthma, ${ }^{12-17}$ methacholine challenge giving similar results to histamine challenge ${ }^{15}$ and being more sensitive than exercise challenge. ${ }^{1617}$ Few epidemiological studies using these techniques for the detection of asthma have been published. ${ }^{618}$ Lee et al $^{18}$ found that one third of 7 year old British children with recurrent wheezing did not respond to histamine inhalation challenge, while one third of a control group of 100 symptomless children did react in some instances to very low concentrations of histamine.

As part of a longitudinal multidisciplinary study of a birth cohort of New Zealand children now aged 9 years, we sought to determine the prevalence of bronchial hyperreactivity to inhaled methacholine and to assess the value of this challenge in determining the prevalence of asthma in childhood. 


\section{Methods}

Children aged 9 years, enrolled in the Dunedin Multidisciplinary Child Development Study, were the subjects of this study. A birth cohort of 1661 surviving infants born at Queen Mary Hospital, Dunedin, from 1 April 1972 to 31 March 1973 has been followed every two years from the age of 3, at which time 1037 children were located and were willing to participate; most were seen again at 5 and 7 years. ${ }^{1}$ At 9 years 815 of these children attended the Dunedin study centre; children examined elsewhere in New Zealand and those whose details were obtained by correspondence have not been included in this report. The characteristics of the children in this longitudinal study, and their comparability at birth with those of the cohort not followed up, have been reported. ${ }^{19}$

The aim of the respiratory assessment was to determine the cumulative prevalence and characteristics of asthma between birth and age 9 . A detailed questionnaire regarding past and current wheezing, coughing, and other respiratory symptoms was administered to the child's parent by a physician. Chest examination, spirometry, and methacholine inhalation bronchial challenge were performed after written informed parental consent had been obtained. All procedures were approved by the Dunedin Hospital ethics committee.

Spirometry was performed with a water sealed Godart spirometer. At least three attempts were made to obtain the best forced expired volume in one second $\left(F_{1}\right)$ and forced vital capacity (FVC). Values for $\mathrm{FEV}_{1}$ and FVC were compared with established predicted values for children. ${ }^{20}$ If $\mathrm{FEV}_{1} / \mathrm{FVC}$ was less than $75 \%$ in a child with respiratory symptoms, or less than $70 \%$ in a symptomless child, methacholine challenge was not undertaken; responsiveness to an inhaled bronchodilator (salbutamol) was assessed instead.

\section{METHACHOLINE CHALLENGE}

Methacholine inhalation challenge was performed according to an abbreviated protocol modified from Chai et al. ${ }^{21}$ Methacholine solutions $(0.025,0.25,2.5$, and $25.0 \mathrm{mg} / \mathrm{ml}$ ) were prepared weekly from freeze dried methacholine chloride (Sigma, USA), stored at $-20^{\circ} \mathrm{C}$ and kept at $4^{\circ} \mathrm{C}$ between tests. After spirometry the child inhaled nebulised methacholine through a closely fitting facemask attached directly to a Hudson nebuliser delivering $0.2 \pm 0.02 \mathrm{ml} / \mathrm{min}$ at an air flow rate of $6 \mathrm{l} / \mathrm{min}$. The child was instructed to take five consecutive breaths from the mask, from functional residual capacity to total lung capacity. Spirometry was repeated $\mathbf{3 0}$ seconds and two minutes after challenge. Increasing concentrations of methacholine were inhaled at intervals of three to four minutes until $\mathrm{FEV}_{1}$ fell to less than $80 \%$ of the besx. $\mathrm{FEV}_{1}$ achieved before that test, or until the maximunt? concentration was reached. The provoking concen ${ }^{\circ}$ tration of methacholine causing a $20 \%$ fall in FEV $\left(\mathrm{PC}_{20} \mathrm{FEV}_{1}\right)$ was calculated by interpolation. $\quad \frac{\bar{\sigma}}{\omega}$

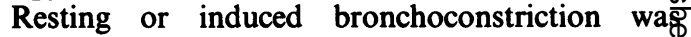
reversed by inhalation of salbutamol $0.5 \%$ adminiso tered undiluted through a Hudson nebuliser at añ airflow rate of $6 \mathrm{l} / \mathrm{min}$ for 1.5 minutes. Improvement in $\mathrm{FEV}_{1}$ was documented five minutes later; a increase of $10 \%$ or more was considered significant

REPEATABILITY AND VALIDATION PROCEDURE Within two months of the initial test a representative subsample of 79 subjects underwent a second study to assess the repeatability of the abbreviated methas choline challenge in children. To validate the abbrev 5 ated challenge procedure, a further 30 selected subjects, 22 of whom had shown reactivity with ou $\vec{f}$ protocol, were recalled for methacholine challenge according to the protocol of Hargreave et al, ${ }^{22} \mathrm{i}$. which twofold concentration increments (methas choline $0.03-32.0 \mathrm{mg} / \mathrm{ml}$ ) were inhaled by tidạ breathing for two minutes from a closely fitting face mask attached directly to a Wright's nebulise delivering $0.13 \pm 0.015 \mathrm{ml} / \mathrm{min}$ at an airflow rate of $6 \mathrm{l} / \mathrm{min}$.

\section{STATISTICAL ANALYSIS}

The relationships between $\mathrm{PC}_{20} \mathrm{FEV}_{1}$ values and sp? rometric and clinical data were explored with $\chi^{2}$ tests. $t$ tests, and analyses of variance. Since differences i percentage fall in $\mathrm{FEV}_{1}$ and in $\mathrm{PC}_{20} \mathrm{FEV}_{1}$ in the repeatability and validation studies were proportiona to the size of the measurement, logarithmic transis formations were carried out before analysis Differences were analysed with the test of reliabilit. described by Fleiss ${ }^{23}$ and the analysis of comparisong studies described by Altman and Bland. ${ }^{24}$

\section{Results}

Of the 1037 children entering the study at age $3,8 \mathrm{in}$ (431 boys, 384 girls) were seen at the study centre ad the age of 9 . Although these represented only half of the birth cohort of 1661 children, they appear to have been a fair reflection of the original sample. The chis dren not entered into the study at the age of 3 did not differ significantly in their birth and perinatal charac teristics from those enrolled in the study, ${ }^{19}$ and the gradual loss of 222 children over the subsequergi six years has not altered significantly the socieे economic or other epidemiologically importanif characteristics of the cohort. 
PHYSIOLOGICAL STUDIES

Eight children did not perform adequately in the spirometric tests because of limited mental ability (2), lack of cooperation (3), or persistent variability of effort (3). Two were excluded because of a physical handicap that affected their ability to use a spirometer, three because they had used a bronchodilator drug within the preceding six hours, and two because they did not complete the methacholine challenge according to the protocol. Data from these 15 children, six of whom had a history of asthma, were excluded from the physiological analysis. Technically satisfactory spirometric tracings were obtained in the remaining 800 children. Methacholine challenge was declined by eight of these children.

\section{Airflow obstruction}

Spirometric evidence of airflow obstruction at rest $\left(\mathrm{FEV}_{1} / \mathrm{FVC}<75 \%\right)$ was found in 27 children $(3.4 \%$ of 800 tested), 17 of them boys; only five of the 27 underwent methacholine challenge. Eight children with an $\mathrm{FEV}_{1} / \mathrm{FVC}$ of less than $70 \%, 14$ with an $\mathrm{FEV}_{1} / \mathrm{FVC}$ of $70-74.9 \%$ who had had recent wheezing, and four whose $\mathrm{FEV}_{1} / \mathrm{FVC}$ was $75 \%$ or more but who clinically had wheezing or a low absolute $\mathrm{FEV}_{1}$ were given salbutamol only. Spirometric values improved after inhalation of salbutamol $(>10 \%$ increase in $\mathrm{FEV}_{1}$ ) in all but three of these 26 children; in 22 the postbronchodilator $\mathrm{FEV}_{1} / \mathrm{FVC}$ exceeded $75 \%$ and in 12 it exceeded $80 \%$. Three children with an $\mathrm{FEV}_{1} / \mathrm{FVC}$ of $70-74.9 \%$ with a trivial history of wheeze or cough and two with no such history were included in the group undergoing methacholine challenge.

\section{Methacholine challenge}

Of 766 children who underwent methacholine bronchial challenge, five $(0.7 \%)$ had a more than $20 \%$ fall in $\mathrm{FEV}_{1}$ after five breaths of methacholine $0.25 \mathrm{mg} / \mathrm{ml}, 31(4.0 \%)$ after methacholine $2.5 \mathrm{mg} / \mathrm{ml}$, and $140(18.3 \%)$ after methacholine $25.0 \mathrm{mg} / \mathrm{ml}$. In all, 176 children $(23.0 \%$ of those without airway obstruction who were tested, or $22.0 \%$ of all children tested; 111 boys, 65 girls) showed a $\mathrm{PC}_{20} \mathrm{FEV}_{1}$ in response to methacholine of less that $25 \mathrm{mg} / \mathrm{ml}$. All of the 176 children showed a greater than $10 \%$ increase in $\mathrm{FEV}_{1}$ after a salbutamol inhalation given to terminate the methacholine response.

There was a weak positive correlation between $\mathrm{PC}_{20} \mathrm{FEV}_{1}$ and initial $\mathrm{FEV}_{1}$ when this was expressed as percentage of predicted $\mathrm{FEV}_{1}(\mathrm{r}=0.21$, $p<0.005$ ), but this accounted for only $4.6 \%$ of the variation in $\mathrm{PC}_{20} \mathrm{FEV}_{1}$. No correlation was found between $\mathrm{PC}_{20} \mathrm{FEV}_{1}$ and initial FVC. The prevalence of reactivity was related to the $\mathrm{FEV}_{1} / \mathrm{FVC}$ ratio; $81.5 \%$ of children with an $\mathrm{FEV}_{1} / \mathrm{FVC}$ below $75 \%$ and $62.5 \%$ of those with an $\mathrm{FEV}_{1} / \mathrm{FVC}$ below $80 \%$ showed a response to salbutamol or methacholine.

No severe or protracted wheezing was induced despite a fall in $\mathrm{FEV}_{1}$ by more than half in four children. Discomforting cough after methacholine in four children was reversed by inhalation of salbutamol. Oxygen and emergency drugs were always available but never required. Bronchial challenge was completed within 15 minutes, or 20 minutes if salbutamol was given to terminate bronchoconstriction.

\section{RELATIONSHIP OF BRONCHIAL REACTIVITY TO} CLINICAL HISTORY

A history of recurrent wheezing was obtained in 220 children. In 73 (9.0\% of all children) wheeze was infrequent (one or two episodes a year) and asthma was classed as trivial; $113(13.9 \%)$ had three or more episodes per year and were regarded as having mild asthma, and a further $34(4.2 \%)$ had sufficiently frequent wheezing (more than one episode a month) to warrant regular treatment and these were classified as having moderate or severe asthma. Nineteen children had a single episode of wheezing only, while recurrent dry cough without wheeze was noted in 94 children; these children could not be considered symptom free and their data are given separately in table 1. Data

Table 1 Relationship between symptoms before the age of 9 and response to bronchial challenge in 8139 year old children

\begin{tabular}{|c|c|c|c|c|c|c|c|}
\hline \multirow[t]{2}{*}{ Symptoms } & \multirow[t]{2}{*}{$\begin{array}{l}\text { Total } \\
\text { number }\end{array}$} & \multirow[t]{2}{*}{$\begin{array}{l}\text { Number } \\
\text { tested }\end{array}$} & \multirow{2}{*}{$\begin{array}{l}\text { No with } \\
\text { reversible resting } \\
\text { airflow } \\
\text { obstruction }\end{array}$} & \multicolumn{3}{|c|}{$\begin{array}{l}\text { Number reacting to } \\
\text { cumulative totals methacholine } P C_{20} F E V_{1}\end{array}$} & \multirow[t]{2}{*}{$\begin{array}{l}\text { Total with } \\
\text { regctive airways } \\
\text { (\% tested) }\end{array}$} \\
\hline & & & & $<0.25$ & $<2.5$ & $\leqslant 25.0(\mathrm{mg} / \mathrm{ml})$ & \\
\hline $\begin{array}{l}\text { None ever } \\
\text { Recurrent dry cough } \\
\text { Single episode of wheezing } \\
\text { Trivial asthma } \\
\quad(1-2 \text { episodes/y) }\end{array}$ & $\begin{array}{r}480 \\
94 \\
19 \\
73\end{array}$ & $\begin{array}{r}466 \\
94 \\
19 \\
73\end{array}$ & $\begin{array}{l}1 \\
0 \\
0 \\
1\end{array}$ & $\begin{array}{l}0 \\
0 \\
0 \\
0\end{array}$ & $\begin{array}{l}6 \\
3 \\
1 \\
2\end{array}$ & $\begin{array}{r}64 \\
23 \\
6 \\
18\end{array}$ & $\begin{array}{l}14 \\
24 \\
32 \\
26\end{array}$ \\
\hline $\begin{array}{l}\text { Mild asthma } \\
(>2 \text { episodes } / y)\end{array}$ & 113 & 108 & 10 & 2 & 10 & 46 & 52 \\
\hline $\begin{array}{l}\text { Moderate or severe asthma } \\
\text { (requiring regular } \\
\text { treatment) }\end{array}$ & 34 & 31 & 11 & 3 & 14 & 19 & 97 \\
\hline Total & 813 & 791 & 23 & 5 & 36 & 176 & 245 \\
\hline
\end{tabular}




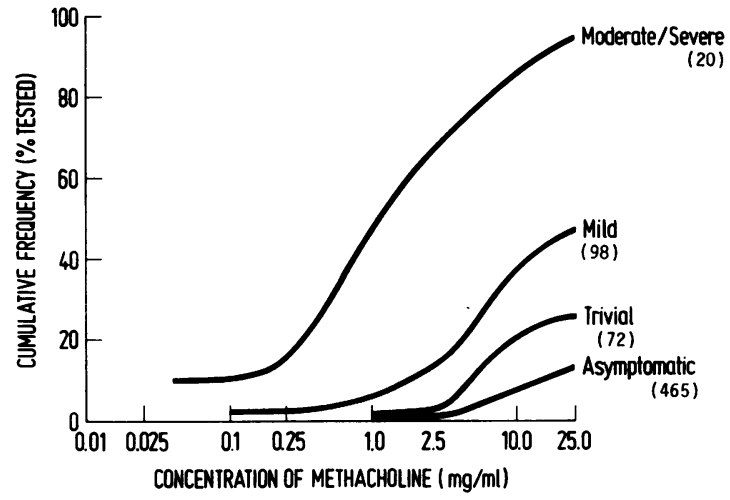

Fig 1 Cumulative frequency of bronchial reactivity in response to increasing concentrations of methacholine in children with and without symptoms who did not have resting airflow obstruction. Numbers in brackets indicate numbers of children tested in each group.

were inadequate in two children. The remaining 480 children $(58.9 \%)$ did not admit to respiratory symptoms up to the age of 9 (table 1 ) and were classified as asymptomatic.

The cumulative frequency of $\mathrm{PC}_{20} \mathrm{FEV}_{1}$ values in wheezing and symptomless children without resting airflow obstruction is shown in figure 1 . Reactivity to methacholine occurred more frequently at lower concentrations in those with more severe asthma. Reactivity was not, however, invariable among children with symptoms (table 1). The prevalence of reactivity to salbutamol and methacholine was directly related to the frequency of episodes during the year before the methacholine challenge (table 2); all with daily wheeze were reactive to methacholine, as were $88 \%$ of those whose episodes occurred at least monthly. But $35 \%$ of children with three or more wheezing episodes in the year before challenge and without resting airflow obstruction did not respond to methacholine $25 \mathrm{mg} / \mathrm{ml}$. The degree of reactivity was related to the interval since the last episode of wheez- ing, a shorter interval being associated with a lower. $\mathrm{PC}_{20}$ FEV $_{1}(\mathrm{p}<0.001)$.

Despite these relationships, $50.5 \%$ of the 220 child? ren with a history of recurrent wheezing did noi respond to the highest dose of methacholine. Of the 147 children with mild or moderate or severe asthm $\%$ at some time during their nine years, $16 \%$ had resting airflow obstruction, $5 \%$ declined methacholine chat lenge, $44 \%$ had a $\mathrm{PC}_{20} \mathrm{FEV}_{1}$ less than $25 \mathrm{mg} / \mathrm{ml}$, and the remaining $35 \%$ failed to achieve a $20 \%$ fall in $\mathrm{FEV}_{1}$ after inhaling methacholine $25 \mathrm{mg} / \mathrm{ml}$. This was not simply related to the frequency or severity of ep? sodes, since in a selected group of 38 children with three to 12 episodes of wheezing in the last year $11 \%$ had resting airflow obstruction, $42 \%$ responded to methacholine, and $47 \%$ did not achieve a $20 \%$ fall if $\mathrm{FEV}_{1}$ after methacholine $25 \mathrm{mg} / \mathrm{ml}$. In this group those with reactivity and those without did not differ in mean age of onset of wheezing or in the intervat" since their last episode.

On the other hand, not all children with bronchia reactivity had had respiratory symptoms. Twenty si $\overrightarrow{0}$ of the 27 children with resting airflow obstruction ha\$ a previous or current history of wheeze or recurrent cough, but only $64 \%$ of the 176 children with a meth acholine $\mathrm{PC}_{20} \mathrm{FEV}_{1}$ value less than $25 \mathrm{mg} / \mathrm{ml}$ had has symptoms. Bronchial reactivity without any previous symptoms was found in 65 children. One had restin reversible airflow obstruction and 64 (41 boys and 23 girls; $13.3 \%$ of all symptomless children) showed response to the doses of methacholine given; of these 40 had $\mathrm{PC}_{20} \mathrm{FEV}_{1}<10 \mathrm{mg} / \mathrm{ml}, 18<5.0 \mathrm{mg} / \mathrm{ml}$, an six $<2.5 \mathrm{mg} / \mathrm{ml}$.

\section{REPEATABILITY AND VALIDATION STUDIES}

The abbreviated challenge was repeated in 79 chil dren, 49 of whom did not respond to methacholine $25 \mathrm{mg} / \mathrm{ml}$ in either test while 14 responded in both tests. Thus $80 \%$ of children retained the sam classification of "reactive" or "non-reactive" on re-

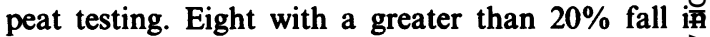
$\mathrm{FEV}_{1}$ in the first test had a fall of under $20 \%$ on reped

Table 2 Relationship between frequency of wheezing episodes in the last year and response to bronchial challenge in 220 children with recurrent wheezing

\begin{tabular}{|c|c|c|c|c|c|c|c|}
\hline \multirow[t]{2}{*}{$\begin{array}{l}\text { Wheezing episodes in } \\
\text { last year }\end{array}$} & \multirow[t]{2}{*}{$\begin{array}{l}\text { Total } \\
\text { number }\end{array}$} & \multirow[t]{2}{*}{$\begin{array}{l}\text { Number } \\
\text { tested }\end{array}$} & \multirow{2}{*}{$\begin{array}{l}\text { No with } \\
\text { reversible resting } \\
\text { airflow } \\
\text { obstruction }\end{array}$} & \multicolumn{3}{|c|}{$\begin{array}{l}\text { Number reacting to } \\
\text { cumulative totals methacholine } P C_{20} F E V_{1}\end{array}$} & \multirow{2}{*}{ 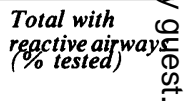 } \\
\hline & & & & $<0.25$ & $<2.5$ & $\leqslant 25.0(\mathrm{mg} / \mathrm{ml})$ & \\
\hline $\begin{array}{l}\text { None } \\
1-2 \\
<\text { Monthly } \\
\text { श Monthly } \\
\text { > Weekly } \\
\text { Daily }\end{array}$ & $\begin{array}{r}60 \\
68 \\
47 \\
24 \\
13 \\
8\end{array}$ & $\begin{array}{r}59 \\
65 \\
45 \\
22 \\
12 \\
8\end{array}$ & $\begin{array}{l}2 \\
3 \\
5 \\
7 \\
1 \\
4\end{array}$ & $\begin{array}{l}0 \\
0 \\
0 \\
2 \\
2 \\
1\end{array}$ & $\begin{array}{l}0 \\
6 \\
5 \\
6 \\
5 \\
4\end{array}$ & $\begin{array}{r}13 \\
25 \\
20 \\
12 \\
9 \\
4\end{array}$ & $\begin{array}{r}25 \\
43 \\
56 \\
86 \\
83 \\
100\end{array}$ \\
\hline
\end{tabular}




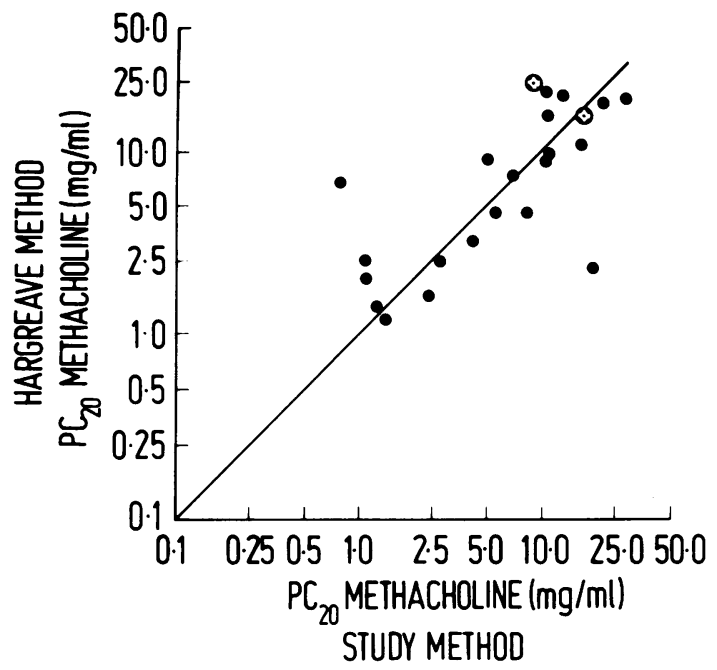

Fig 2 Comparison of $P C_{20} F E V_{1}$ obtained by the abbreviated method (abcissa) and by the Hargreave protocol (ordinate) in 23 children. Results from seven nonresponders are not shown. The open circles indicate $P C_{15}$ data for both methods when $P C_{20}$ was not achieved by one protocol.

testing, and eight vice versa; of these 16 whose classification changed, six had a $19.0-19.9 \%$ fall in $\mathrm{FEV}_{1}$ in response to the concentration which in the other test had induced a greater than $20 \%$ fall in $\mathrm{FEV}_{1}$. When the analysis of Fleiss ${ }^{23}$ was applied to these data, the test gave a moderate coefficient of reliability (kappa $=0.50($ SE $0.01 ; p<0.001)$ ). In addition, the paired $t$ test applied to the logarithmically transformed data from the 14 children responding on both occasions showed no bias from one test to the other $(t=0.08, \mathrm{df}=13 ; \mathrm{p}=0.94)$. The mean ratio of $\mathrm{PC}_{20} \mathrm{FEV}_{1}$ in test 1 and test 2 was 0.94 , not significantly different from 1.00 (95\% confidence interval $0.63-1.41^{24}$ - that is, less than one doubling concentration of methacholine).

Methacholine reactivity measured with the abbreviated protocol was compared with that determined with the longer protocol of Hargreave et $a^{22}$ in 30 selected children. In seven children neither method produced a significant fall in $\mathrm{FEV}_{1}$. In the remaining 23 children comparison of the methacholine concentrations required to provoke a $15 \%$ or $20 \%$ fall in $\mathrm{FEV}_{1}$ showed good agreement between the two techniques (fig 2). In only four children was the difference in $\mathrm{PC}_{20} \mathrm{FEV}_{1}$ between the two techniques greater than a twofold concentration step; three of these four had current asthma. A paired $t$ test on the logarithmically transformed data showed no bias from one method to the other $(t=0.38, \mathrm{df}=22 ; \mathrm{p}=0.71)$. The mean ratio of $\mathrm{PC}_{20} \mathrm{FEV}_{1}$ determined by our study method and the Hargreave method was 1.02 (95\% confidence interval $0.60-1.73^{24}$ - that is, less than one doubling concentration of methacholine).

\section{Discussion}

In this study we added measurement of bronchial reactivity to a clinical and questionnaire survey of asthma prevalence in a birth cohort of over 8009 year old children. An abbreviated methacholine challenge protocol proved practicable in an epidemiological setting and was accomplished without incident. The longer methacholine challenge protocol of Hargreave and colleagues ${ }^{1422}$ was not used because of time limitations and the likelihood that children subjected to a lengthy protocol would become fatigued and bored and so perform less well in the spirometric tests. Chatham et $a l^{25}$ compared a similar abbreviated methacholine inhalation challenge with the longer protocol and found the abbreviated protocol provided a comparable measure of bronchial reactivity. Our validation study showed close agreement between the $\mathrm{PC}_{20}$ values obtained by the short and long protocols. In only four children, three of whom had current asthma, was the difference in $\mathrm{PC}_{20} \mathrm{FEV}_{1}$ between the two methods greater than a twofold concentration increment. The interval of up to two months between tests in the repeatability study was longer than ideal, and may have allowed bronchial reactivity to change in some children as a result of intercurrent infection or allergen exposure.

We found that $25 \%$ of the 9 year old childhood population had resting airflow obstruction reversed by a $\beta$ sympathomimetic aerosol, or had a $\mathrm{PC}_{20} \mathrm{FEV}_{1}$ of less than $25 \mathrm{mg} / \mathrm{ml}$ inhaled methacholine. Heightened bronchial responsiveness is a common phenomenon in childhood. Considerable overlap in bronchial responsiveness was, however, found between children with and without symptoms; $13.9 \%$ of symptomless children tested showed reversible bronchoconstriction or reactivity to methacholine $25 \mathrm{mg} / \mathrm{ml}$, while $35 \%$ of those with clinically relevant wheezing did not show a $20 \%$ fall in $\mathrm{FEV}_{1}$ with methacholine. The distribution of bronchial reactivity in the population is likely to be a continuum rather than bimodal. On the basis of a $20 \%$ fall in $\mathrm{FEV}_{1}$ after five breaths of methacholine $25 \mathrm{mg} / \mathrm{ml}$ as evidence of heightened bronchial reactivity, some children with no recall of wheeze or recurrent dry cough showed bronchial reactivity, while some with symptoms suggestive of asthma did not. These findings are similar to those of Lee et $\mathrm{l}^{18}$; one third of their 7 year old subjects with recurrent wheeze failed to respond to inhalation of histamine $16 \mathrm{mg} / \mathrm{ml}$, while one third of symptomless children did respond. Clearly, bronchial reactivity to methacholine is not 
synonymous with asthma; a single negative response to challenge does not negate the clinical diagnosis. Bronchial reactivity to other potential provocationsexercise, temperature change, infection, exposure to allergens - could possibly be present in the absence of methacholine sensitivity, and the latter may vary with time. Aquilina et $a l^{26}$ and Empey et al ${ }^{27}$ showed that histamine reactivity was increased in normal subjects immediately after upper respiratory tract infections. Laitinen and $\mathrm{Kava}^{28}$ found no increase in histamine induced change in specific airway conductance in healthy subjects given a nasal inoculation of influenza A virus, whereas asthmatic subjects given the same inoculation showed increased reactivity.

Children with a history of wheezing showed significant relationships between the degree of airway reactivity and both the frequency of symptoms over the previous year and the interval between the most recent episode and the methacholine challenge. A relationship between bronchial reactivity and the frequency and severity of clinical asthma has been found repeatedly ${ }^{202-32}$ but bronchial reactivity without symptoms is less well documented. While some children reported as showing asymptomatic bronchial reactivity may have had symptoms not recalled by the mother, the interval from the episode to the methacholine challenge would be most likely to be long and the severity of the episode minimal for it not to be recalled on direct and searching questioning. The present study confirms the findings of Lee et al $^{18}$ - namely, that bronchial hyperreactivity may be present in children in the absence of respiratory symptoms.

Simonsson ${ }^{33}$ tabled seven reports of bronchial reactivity to methacholine in "normal" adult subjects; the maximum number of subjects in any one study was $62 .{ }^{13}$ The concentrations and doses of methacholine administered and the measurement of lung function varied but these studies suggest a degree of bronchial hyperreactivity in the normal adult population similar to that in children. Heightened bronchial responsiveness in adults may have its origins in childhood. Whether increased responsiveness continues to be asymptomatic, or perhaps predisposes to the later development of asthma or airflow obstruction in patients with chronic bronchitis, ${ }^{34}$ is conjectural; and the question could be answered only by long term follow up of children such as these.

In summary, we have shown that $25 \%$ of 9 year old children had evidence of airway reactivity, revealed either by resting airflow obstruction relieved with salbutamol or by responsiveness to inhalation of methacholine. While the presence of airway reactivity was associated broadly with symptoms of asthma, a substantial number of children ( $8 \%$ of 800 tested) had mild or moderate increases in airway reactivity but denied any respiratory symptoms. On the other hand, $\stackrel{x}{x}$ $35 \%$ of children with recent or past histories of more than trivial wheezing did not show increased $\stackrel{\text { ? }}{?}$ responsiveness to methacholine. We conclude that? heightened bronchial responsiveness is a common $\frac{\bar{\sigma}}{\bar{s}}$ phenomenon in childhood but that bronchial chal- $\frac{\text { क }}{\sigma}$

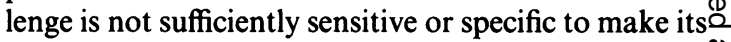
use in epidemiological studies of asthma mandatory. ڤొ Rather, for both epidemiologist and clinician, $a_{\vec{O}}$ detailed history indicating recurrent episodes of wheezing should lead to a diagnosis of asthma.

The assistance of many professional and volunteer $\overrightarrow{\vec{x}}$

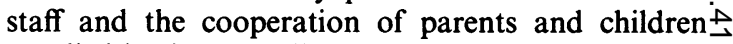
enrolled in the Dunedin Multidisciplinary Child Development Study is gratefully acknowledged. This work was supported by grants from the Otago Med- $\omega$ ical Research Foundation, the Medical Research은 Council of New Zealand, the National Children's Health Research Foundation, the Medical Research $\frac{D}{0}$ Distribution Committee, the University of Otago bequest funds, the Department of Health, and the $\overrightarrow{0}$ Department of Education.

\section{References}

1 Sears MR, Jones DT, Silva PA, Simpson A, Williamsס SM. Asthma in seven year old children: a report from the Dunedin Multidisciplinary Child Development Study $\overrightarrow{\overline{0}}$ NZ Med J 1982;95:533-6.

2 Speight ANP, Lee DA, Hey EN. Underdiagnosis and undertreatment of asthma in childhood. Br Med J $1983 \frac{7}{\circ}$ 286: 1253-6.

3 Konig P. Hidden asthma in childhood. Am J Dis Child 1981;135:1053-5.

4 Milne GA. The incidence of asthma in Lower Hutt. $N \not{x}$ Med J 1969;70:27-9.

5 Anyon CP, Kiddle GB. The prevalence of wheezy chil dren in Lower Hutt. NZ Med J 1974;79:822-3.

6 McQueen F, Holdaway MD, Sears MR. A study of asthma in a Dunedin suburban area. NZ Med $J 1979$ 을

7 Stanhope JM, Rees RO, Mangan AJ. Asthma and wheeze in New Zealand adolescents. NZ Med J 1979? 90:279-82.

8 Williams H, McNicol KN. Prevalence, natural history and relationship of wheezy bronchitis and asthma in chil $\mathrm{T}$ dren. An epidemiological study. Br Med J 1969;iv:321-5ᄋ

$9 \mathrm{McNicol}$ KN, Williams HE. Spectrum of asthma in chil- $-\mathrm{W}$ dren. 1 - Clinical and physiological components. $\mathrm{Br} \mathrm{Med}$ J 1973;iv:7-11.

10 Dodge RR, Burrows B. The prevalence and incidence of asthma and asthma-like symptoms in a general population sample. Am Rev Respir Dis 1980;122:567-75.

11 Gregg I. Epidemiological Aspects. In: Clark TJH, Godfrey S, eds. Asthma. 2nd ed. London: Chapman and Hall, 1983:242-84.

12 Kiviloog J. Bronchial reactivity to exercise and meta- $\frac{\sim}{\Phi}$ choline in bronchial asthma. Scand J Respir Dis 1973음
54:347-58. 
13 Laitinen LAI. Histamine and metacholine challenge in the testing of bronchial reactivity. Scand J Respir Dis 1974;86, suppl:9-48.

14 Juniper EF, Frith PA, Dunnett C, Cockroft DW, Hargreave FE. Reproducibility and comparison of responses to inhaled histamine and methacholine. Thorax 1978; 33:705-10.

15 Spector SL, Farr RS. A comparison of methacholine and histamine inhalations in asthmatics. J Allergy Clin Immunol 1975;56:308-16.

16 Eggleston PA. A comparison of the asthmatic response to methacholine and exercise. $J$ Allergy Clin Immunol 1979;63:104-10.

17 Kiviloog J. Variability of bronchial reactivity to exercise and methacholine in bronchial asthma. Scand $J$ Respir Dis 1973;54:359-68.

18 Lee DA, Winslow NR, Speight ANP, Hey EN. Prevalence and spectrum of asthma in childhood. $\mathrm{Br}$ Med J 1983;286:1256-8.

19 McGee RO, Silva PA. A thousand New Zealand children: their health and development from birth to seven. Auckland: Medical Research Council of New Zealand, 1982. (Special Report No 8.)

20 Helliesen PJ, Cook CD, Friedlander L, Agathon S. Studies of respiratory physiology in children. Pediatrics 1958;22:80-93.

21 Chai H, Farr RS, Froehlich LA, et al. Standardization of bronchial inhalation challenge procedures. J Allergy Clin Immunol 1975;56:323-7.

22 Hargreave FE, Ryan G, Thomson NC, et al. Bronchial responsiveness to histamine or methacholine in asthma: measurement and clinical significance. J Allergy Clin Immunol 1981;68:347-55.

23 Fleiss JL. Statistical methods for rates and proportions. New York: John Wiley and Sons, 1973.

24 Altman DG, Bland JM. Measurement in medicine: the analysis of method comparison studies. Statistician 1983; 32:307-17.
25 Chatham M, Bleecker ER, Norman P, Smith PL, Mason P. A screening test for airways reactivity. An abbreviated methacholine inhalation challenge. Chest 1982;82:15-8.

26 Aquilina AT, Hall WJ, Douglas RG, Utell MJ. Airway reactivity in subjects with viral upper respiratory tract infections: the effects of exercise and cold air. Am Rev Respir Dis 1980;122:3-10.

27 Empey DW, Laitinen LA, Jacobs L, Gold WM, Nadel JA. Mechanisms of bronchial hyperreactivity in normal subjects after upper respiratory tract infection. Am Rev Respir Dis 1976;113:131-9.

28 Laitinen LA, Kava T. Bronchial reactivity following uncomplicated influenza $A$ infection in healthy subjects and in asthmatic patients. Eur J Respir Dis 1980;61, suppl 106:51-8.

29 Spector SL, Staudenmayer H, Kinsman RA, Fukuhara J, Westmoreland C. Methacholine and histamine inhalation challenges in asthma: relationships to age of onset, length of illness and pulmonary functions. Allergy 1979; 34:167-73.

30 Juniper EF, Frith PA, Hargreave FE. Airway responsiveness to histamine and methacholine: relationship to minimum treatment to control symptoms of asthma. Thorax 1981;36:575-9.

31 Murray AB, Ferguson AC, Morrison B. Airway responsiveness to histamine as a test for overall severity of asthma in children. J Allergy Clin Immunol 1981;68: 119-24.

32 Ryan G, Latimer KM, Dolovich J, Hargreave FE. Bronchial responsiveness to histamine: relationship to diurnal variation of peak flow rate, improvement after bronchodilator, and airway calibre. Thorax 1982;37:423-9.

33 Simonsson BG. Clinical implications of bronchial hyperreactivity. Eur J Respir Dis 1980;61, suppl 106:7-18.

34 Ramsdell JW, Nachtwey FJ, Moser KM. Bronchial hyperreactivity in chronic obstructive bronchitis. Am Rev Respir Dis 1982;126:829-32. 